\title{
Hydrogeological Conditions and Natural Factors Forming the Regime of Groundwater Levels in the Ivano-Frankivsk Region (Ukraine)
}

\author{
Lidiia Davybida ${ }^{* *}$, Dmytro Kasiyanchuk', Liudmyla Shtohryn', \\ Eduard Kuzmenko', Mariia Tymkiv ${ }^{1}$ \\ 1 Department of Geotechnogenic Safety and Geoinformatics, Ivano-Frankivsk National Technical University of \\ Oil and Gas, 15 Karpatska Street, Ivano-Frankivsk, 76019, Ukraine \\ * Corresponding author's e-mail: davybida61085@gmail.com
}

\begin{abstract}
The purpose of the article is to carry out a complex analysis of conditions and natural factors forming the hydrogeological regime as well as to integrate the existing information and groundwater monitoring data in Ivano-Frankivsk region for further creating the unified automated system to collect, process, analyze and store the monitoring observation data. The authors offer methodology, which is based on the geoinformation approach, for organizing and monitoring of the groundwater. The structure of spatial and attributive data that afford to systemize the existing schemes of the hydrogeological zoning as well as the results of long-term observations over variability of the groundwater levels and factors forming the hydrogeological regime were developed. The new approaches for improving the techniques to forecast the groundwater level with due consideration of temporal patterns for changes in water level, the Moon phases and seismic activity, are proposed. The obtained results are considered as an informational basis for reorganization of the state hydrogeological monitoring on the example of Ivano-Frankivsk region.
\end{abstract}

Keywords: groundwater, hydrogeological zoning, geodatabase, the Moon phases, earthquakes

\section{INTRODUCTION}

The groundwater, as the most dynamic component of the geologic environment, responds quickly to changes in their forming conditions and, hence, to the impact of anthropogenic factors. It means that the condition peculiar to the underground hydrosphere, and primarily, to the groundwater, as the first constant water-bearing formation, may serve as an indicator of the ecological state of the geological environment as a whole. Nowadays, it is believed that the functioning of a scientifically grounded stationary system of hydro-geological monitoring supplies the most complete information about the groundwater condition [Koshliakov et al. 2016, Shestopalov et al. 2016]. However, since such system is practically absent in the most territories of Ukraine, and in the studied Ivano-Frankivsk region in particular, and its creation and effective functioning is problematic because of purely economic reasons, we have to develop the new approaches to obtain and process information on the groundwater conditions, as well as on the dynamics of their levels first of all.

Upon analyzing the current experience in the application of the geoinformation approach to optimization of groundwater monitoring [Hudak et al. 1992, Ben-Jema et al. 1994, Berezko et al. 2012, Brovko et al. 2015, Pivovarova 2016, Tymkiv et al. 2016], the authors identify the priority tasks to renovate the state network of hydrogeological monitoring and to adapt it to the European standards in the shortest possible period. These tasks are as follows: inventory of the observation points, evaluation of their representativeness, and development of the concept for monitoring system reformation as well as formation of a single database with the involvement of GIS-technologies. 
It is well known that the regime of underwater is affected by the exogenous factors (meteorological, hydrological characteristics, lunar tides), the endogenous factors (tectonic movements, volcanism, and earthquakes) and the technological factors (water intake). It is clear that the climatic factors (atmospheric precipitations, air temperature) and the hydrological factors (a regime of surface stream flows) have effect on the hydrogeological regime formation [Ruban et al. 2005] and, in particular, on the examined area, which is characterized by natural or slightly degraded regime undergoing the influence of local technological factors. First, the earthquakes should be enumerated among the geological factors, the effect of which may be fixed by hydrogeological observations. The impact of earthquakes on the groundwater regime is usually episodic and it is the most often seen in sharp changes in the level of pressure water. The study of peculiarities in changes of the natural regime of groundwater, in turn, gives the possibility to monitor the process of earthquake emerging. It is noted in scientific papers [Adushkin et al. 2017; Maréchal et al 2002] that the lunar and solar tides are clearly distinguished in the variations of level of underground water. It is confirmed by the spectral analysis. It is believed that the monthly lunar tides within the pressure water have an influence on the water-bearing horizon by periodically increasing the load, changing the elastic state of the water-bearing horizon. The influence of tidal force is fixed in water-table wells, because the gravity forces stretch the
Earth's crust, thus increasing the level of groundwater. These, so called ground, tidal oscillations are measured only by few centimeters and they have clear periodicity in 12 and 24 hours, and less clear periodicity in 14 and 28 days.

It should be noted that there has been no purposeful study of the influence produced by the seismic activity and lunar cycles on the hydrogeological regime formation in the Ivano-Frankivsk region. At the same time, it has been studied for nowadays that in the Western Ukraine, abnormal rains (one of the direct factors of influence over variability of the groundwater levels) usually occur in the Last or the First Moon Quarter. As a rule, the maximum precipitations are recorded on the first - third day of the Moon Phase [Shtohryn et al. 2015]. The cycles of extreme precipitations in 5.5-6.9.4 and 11 years are present in the spectra of all specified phases and in the whole period, as well as they are multiple of the solar activity periods and the Moon cycle (Fig. 1).

The purpose of the study is to integrate the existing information and groundwater monitoring data as well as the factors forming the hydrogeological regime in the Ivano-Frankivsk region for further creation of the unified automated system to collect, process, analyse and store the monitoring observation data. The Ivano-Frankivsk region was chosen due to three reasons: 1 ) its location on the border of mountainous areas and flat terrains; 2 ) the availability of output data; 3 ) possibility to spread the findings obtained to other territories of Ukraine and abroad regions.

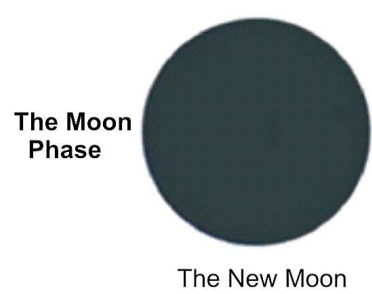

Number of registered heavy rains

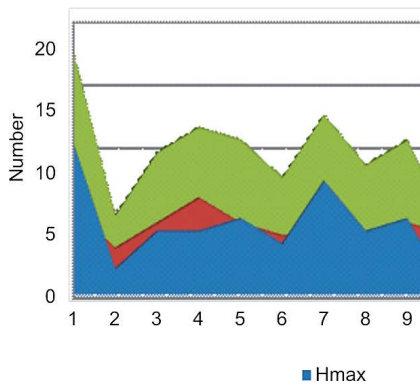

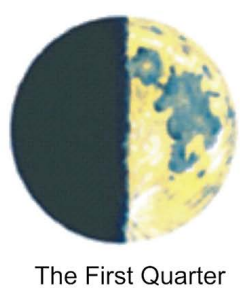

5

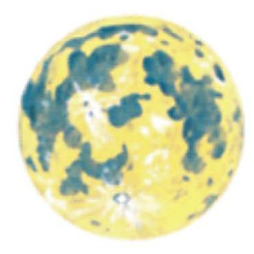

The Full Moon

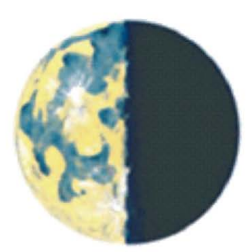

The Last Quarter
13

Figure 1. Diagram of interrelations between the Moon phases and extreme levels of groundwater 


\section{MATERIALS AND METHODS}

The studied Ivano-Frankivsk region is characterised by the well-developed river network and belongs to the area, which is one of the richest areas in Ukraine in terms of surface water resources. However, this area takes one of last places with regard to the reserves of the drinking groundwater. Despite this fact, the individual water supply to the population and enterprises of the region is mainly carried out by the groundwater. The first water-bearing horizon is used the most often.

According to the zoning of Ukraine under the conditions for the groundwater formation (Fig. 2), Ivano-Frankivsk region is located in the area of such hydrogeological regions as Volyn-Podolian Artesian Basin and Precarpathian Artesian Basin as well as the Carpathian folded zone [Shestopalov et al. 2010]. The complex geological structure of the area has caused a great variety of its hydrogeological conditions, which are unequal for the groundwater using and its vulnerability to the industrial pollution. It should be stressed that the basic current network of the state hydrogeological monitoring, which in 2016 included only 5 observation wells and 2 wells within the water intake area in Ivano-Frankivsk region, did not fulfil the assigned functions and it requires serious reorganization and further development [Shestopalov et al. 2016].

The materials by 'Geoinform of Ukraine', State Research-and-Production Enterprise, Ukrainian State Geological Prospecting Institute, Institute of Geological Sciences of National Academy of Science of Ukraine, concerning the hydrological zoning pursuant to the water exchange principle, location of hydrogeological observation points as well as the results of long-term observations have been used for creating the geodatabase to provide the functioning of the hydrogeological monitoring system within the Ivano-Frankivsk region. The spatial and attributive information is supplemented by the topographical data and brought to a single scale $(1: 100000)$ and format of digital cartographic models in GIS MapInfo Professional (Gauss-Krüger projection, Pulkovo, 1942, zone 6). The results of the monitoring observations are stored in the external relational database and they may be adjoined to the spatial objects (hydrogeological monitoring stations) using unique codes of the observations points.

The hydrogeological areas identified by various principles are considered as a territorial basis to conduct the groundwater monitoring as well as projecting and improving the current network of observation wells. In this paper, the zoning scheme based on groundwater formation conditions as well as the scheme of functional zoning pursuant to the basin principle are chosen as the initial cartographic materials that characterize conditions creating the regime on the area.

Zoning scheme (Fig. 2) has been developed pursuant to the conditions of the groundwater formation in the Ukrainian State Geological Prospecting Institute, which is detailed in the paper [Ruban et al. 2005]. The zoning scheme is formed in accordance with the geological and structural principle of hydrogeological zoning, which takes into account the heterogeneity of the Earth's crust composition and structure. The regions, which are covering the largest geo-structural units the hydrogeological massifs (such as basins of produced-block water and basins of fracture-vein water) as well as artesian basins (produced water basins), are allocated at the core of the scheme. There are smaller taxonomic units that include the hydrogeological areas representing a part of the groundwater basin expressed on the certain territory, which is characterised by a specific combination of geological structure, relief, climatic, hydrological and, eventually, hydrogeological conditions. One may distinguish the subareas, which differ by some features of geological structure, relief and climatic conditions, within a majority of areas. The smallest taxonomic units of typing, which characterize the stratigraphic features of the conditions for the groundwater formation in the profile, are the landscape hydrogeological complexes (LHC). They include separate areas, where the first water bearing horizon is deposited having the defined stratigraphic sections, which reflect the structure of the aerated zone, water-bearing and waterproof layers and, to a certain extent, stipulate the peculiarities of the groundwater recharge and discharge as well as the reservoir properties of the upper layer of rocks, where their formation takes place. LHC are azonal units of zoning and they are characterized by common features of the most hydrogeological areas, mainly within the groundwater basins. In general, 26 varieties of plain LHC and 6 varieties of mountainous LHC are identified in Ukraine. There are 10 varieties (7 plain LHC and 3 mountainous LHC) in the Ivano-Frankivsk region. The indexation of LHC is specified in accordance with the hydrogeological zoning scheme of Ukraine [Ruban et al. 2005]. 


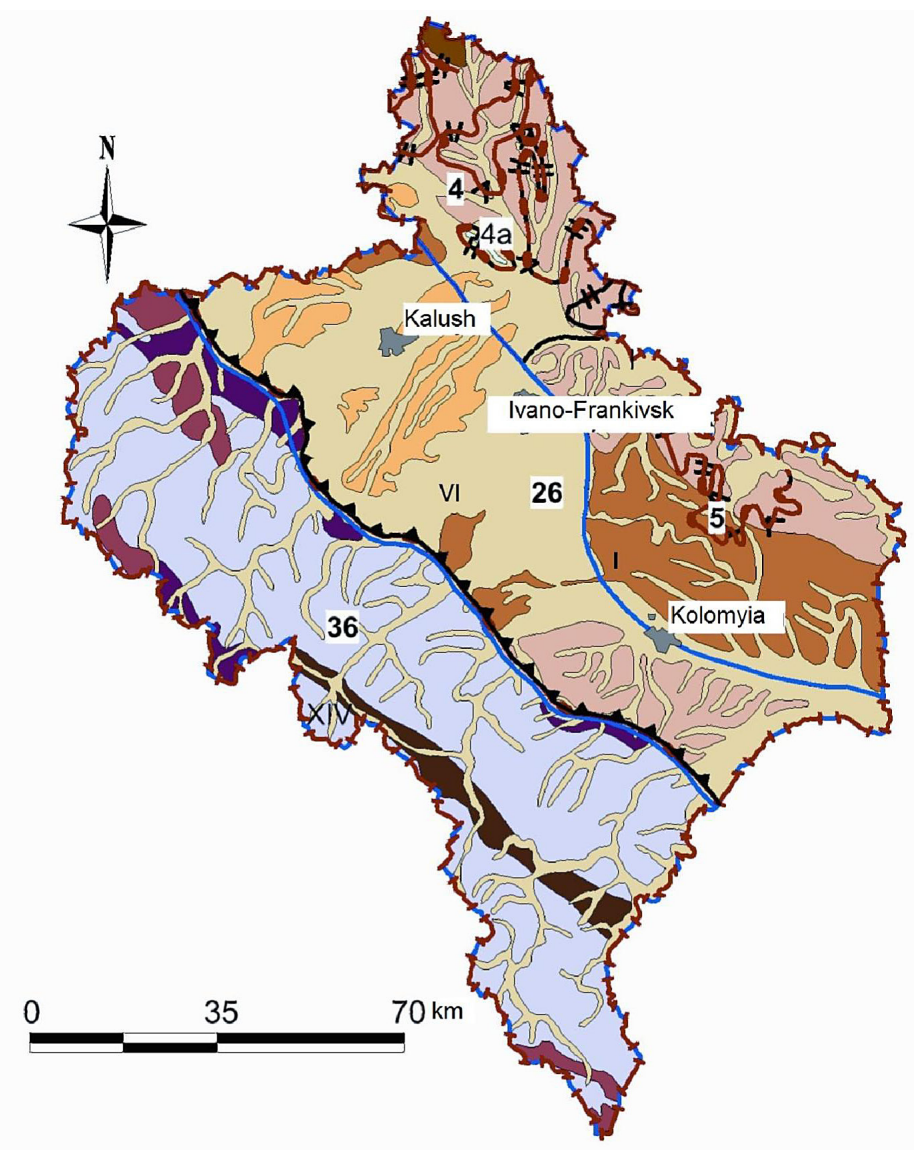

LEGEND

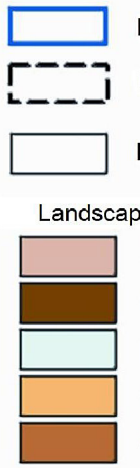

Hydrogeological basins

Hydrogeological areas

$\neg \longmapsto J$ Region borders

Hydrogeological subareas

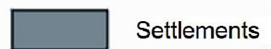

Landscape hydrogeological complexes

Contours of distribution of waterproof rocks

$5 a(9)$

$9 a(17)$

$7 a(13)$

$6 a(11)$

$4 a(7) 11$

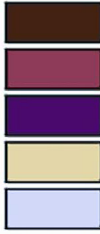

$\mathrm{M} 3$

$7 b(14)$

$\mathrm{M} 2$

- clay, argillits

marl, cretaceous

--- argillits, pudding rocks

crust of weatherina

$4 a(7) !$

M1

Figure 2. Zoning of Ivano-Frankivsk region according to the formation conditions and groundwater occurrence: I - Volyn-Podolian Artesian Basin (4 - Podolian area (4a - Roztochya-Opilian suberea), 5 - Prut-Dniester area); VI - Precarpathian Artesian Basin (26 - Precarpathian area); XIV - Carpathian Groundwater Basin of

(36 - Mountain Carpathian area)

The scholars of the Institute of Geological Sciences of National Academy of Science of Ukraine have developed a functional zoning scheme, according to the basin principle (under the conditions of water exchange in the upper hydrogeological layer) [Shestopalov et al. 2010] (Fig. 3). The given scheme may be considered as the basic one for reorganization of the state system for the groundwater monitoring, in accordance with the principles of the EU Water Framework Directive, and for transition from the administrative-territorial approach to creation of the integrated basin model to control the water resources. This model envisages coordination of water protection measures as to the surface water and groundwater, which belong to the common ecologic, hydrologic, and hydrogeological system. The system for studying the groundwater drainage is based on the dynamic features of objects allocated according to the principle of groundwater runoff unity 
from the areas of drainage formation to its main discharge, which is controlled by a single closed balance of the groundwater. Within the hydrogeological structures, one may allocate the water exchange basins of the first order, which are characterized by single or close trends of the regional water exchange. The hierarchy of this zoning is as follows: there are basins of sea drainage (regions) and main rivers that flow into the seas (provinces). The next zoning level takes into account the peculiarities of the hydrogeological conditions as well as the close trends of lateral water exchange; thus, the basins of rivers' groundwater flow are united within the bounds of the single zoning units (provinces), where the subareas corresponding to water exchange basins of different main rivers tributaries are allocated. The water exchange basins, sizes and boundaries of which are determined by sizes and configuration of the river basins as a rule, should be considered as characteristic systems with homogenous regime in forecasting the changes in level of the ground water, which is a part of the underground hydrosphere that is most closely related to the external surface factors forming the groundwater recharge and discharge. The expediency of monitoring study

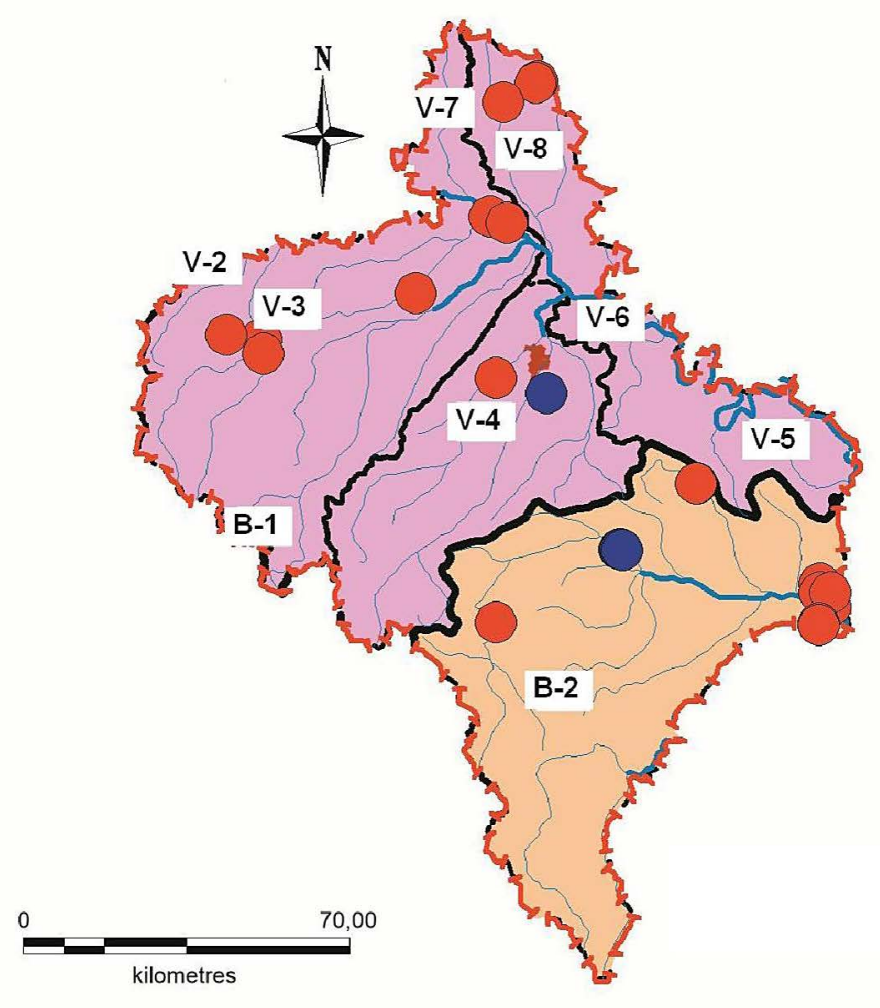

LEGEND

Hydrogeological provinces

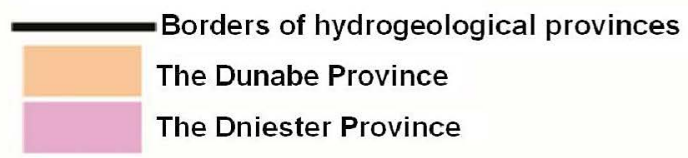

\section{Hydrogeological districts}

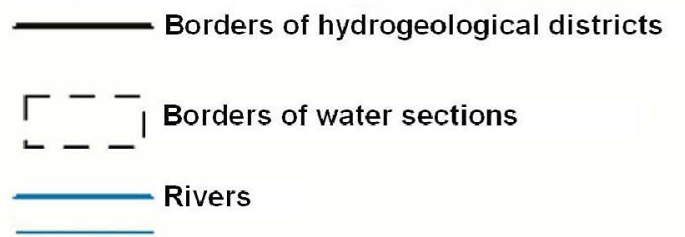

Regime points of the state network of hydrogeological monitoring

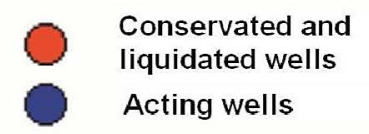

Administrative center

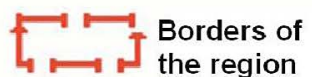

Figure 3. Zoning of the Ivano-Frankivsk region under the conditions for water exchange formation in the hydrogeological structures 
for both surface and underground water is also confirmed by the synchronicity of the long-term variability of the mid-annual surface water flow and the annual average depth of the groundwater level. The synchronicity is observed for both the actual values of the regime elements and for long-term trends established for the hydrological stations and hydrogeological wells located in the same hydrogeological district [Davybida 2017]. The studied territory of Ivano-Frankivsk region belongs to the hydrogeological provinces of the Dniester River and the Dunabe River, which are divided within the studied region in 7 hydrological districts (V-2 - the Strypa River, V-3 - the Svich River and the Limnytsia River, V-4 - the Bystrytsia Nadvirnianska River and the Bystrytsia Solotvynska River, V-5 - the right bank of the Dniester River from the mouth of the Bystrytsia River to the mouth of the Liadova River, V-6 the Stryvigora River and the Vereshchytsia River, V-7 - the Davydivka River and Svira River, V-8 the Gnyla Lypa River and the Zolota Lypa River) and 2 hydrogeological districts (B-1 - the Tysa River, B-2 - the Prut River).

In order to integrate the spatial data, the spatial binding of raster maps was conducted and they were transferred into the vector format by digitalization. A geodatabase was created that includes the following layers with the relevant attributes:

1. hydrological monitoring stations (code, number, type, depth, coordinates $\mathrm{X}$ and $\mathrm{Y}$, type of water-bearing horizon, regime type, disturbance of regime);

2. hydrological provinces (code, index, water exchange basin);

3. hydrological districts (code, index, water exchange basin);

4. water-resource regions (code, index, departmental subordination);

5. hydrological basins, allocated under the conditions of formation and groundwater occurrence (code, index, basin);

6. hydrogeological district (code, index, district);

7. hydrogeological sub-district (code, index, sub-district);

8. landscape hydrological complexes (code, index, age of rocks of the aeration zone, rocks of the aeration zone, chemical composition of the aeration zone, limit values of aeration zone depth, limit values peculiar to the coefficient of the aeration zone filtration, age of rocks contained in the water-bearing formation; rocks of the water-bearing formation; chemical compo- sition of waters contained in the ground waterbearing horizon, limit values peculiar to the filtration coefficient of water-bearing horizon, age of watercourse rocks, filtration coefficient of watercourse rocks, limit values of mineralization, water hardness and $\mathrm{pH}$ index;

9. vector layers of the basic information including administrative boundaries, settlements, roads, rivers, vegetation, relief.

The factual input database contains the information on the structure of the state hydrogeological monitoring network (spatial coordinates and attributive data), location of hydrogeological points, meteorological points as well as the results of long-term regime observations over the groundwater levels, presented in the form of average monthly values of groundwater depth levels calculated under the data of timing observations, results of observations on the variability of weather and climate characteristics (average annual air temperature, amount of precipitation), long-term change of numerical characteristics peculiar to the geological features (the energy of earthquakes) and the cosmogenic features (the Moon phases, solar activity) required to form the hydrogeological regime.

It should be noted that due to the absence of observation wells for intermediate waters as well as of the results of observations over the hydrochemical and hydrothermal regime in the Ivano-Frankivsk region, the present informative elements were not entered into the developed database and they are considered as an object of separate study.

\section{RESULTS AND DISCUSSION}

The spatial analysis concerning the subject layers of hydrogeological monitoring stations and hydrogeological zoning taxon shows the inefficient location of the observation wells within the studied territory. In addition, all observations are conducted over the groundwater regime only. However, given the characteristic features of the conditions peculiar to the groundwater regime formation, number, configuration and location of hydrogeological districts in Ivano-Frankivsk region, it is necessary to increase the number of hydrogeological monitoring stations up to 18-20 (3 wells per each hydrogeological district allocated under the water exchange principle; they should 
be located in such a way so as to be representative for riverside, terraced and water-dividing types of the groundwater regimes). Another criterion for choosing the location of the observation point is the LHC occurrence (Fig. 2). The location of the monitoring stations with due allowance for conditions of the hydrogeological regime formation will permit to obtain more complete information and to organize a random placement of wells to provide the uniformity and independence of tests. The next stage of the study is determination of optimal coordinates to locate the monitoring wells on the basis of a formal statistical estimation of the points' density, taking into account the given extrapolation error of the investigated parameters in a GIS environment.

An outcome analysis of long-termed observations over the groundwater level, the weather and climate characteristics as well as over the hydrological regime creating factors typical for the observation territory (Fig. 4) has established the presence of synchronically changed rhythm and significant relation, first of all, for the time series of the average annual groundwater levels and the series of average annual water consumption, the value of which is connected with the modulus of flow, including such factors as surface and groundwater flow. The regime of the surface water, in its turn, is also determined by climatic factor having an influence on the groundwater.

Synchronicity of the long-term variability of the annual average discharge of surface flows and the average annual depths of groundwater levels confirms the feasibility of joint monitoring studies for surface water and groundwater in the studied region, as provided by Water Framework Directive [Directive 2000]. The established regularities may be used for renovating the time series of observations over the groundwater levels, for bringing them to a single timeframe, and for drawing up the medium and long-term hydrogeological forecasts.

In order to improve the reliability of forecasting the annual regime of variability peculiar to the groundwater levels as well as the examination of its interconnection with the seismic activity in the studied Ivano-Frankivsk region, the extreme values of groundwater levels in five wells from 1973 to 2003 were analyzed. These wells were drilled into the water-bearing low upper quaternary alluvial horizon $\mathrm{AQ}_{1-3}$ within Volyn-Podolian Artesian Basin. The location of the wells may be set by the boundary coordinates East Longitude $25^{\circ} 54^{\prime}-25^{\circ} 57^{\prime}$, North Latitude $48^{\circ} 44^{\prime}-48^{\circ} 48^{\prime}$. The considered earthquakes were registered within the region and adjacent areas with coordinates East Longitude $24^{\circ}-24^{\circ} 6^{\prime}$, North Latitude $47^{\circ} 7^{\prime}$ $-48^{\circ} 8^{\prime} 9$ (Table 1).

The extreme values of groundwater levels, which were calculated according to the periodic measurements including season levels (pre-spring minimum level $\left(\mathrm{H}_{1}\right)$, spring maximum level $\left(\mathrm{H}_{3}\right)$, summer-autumn minimum level $\left(\mathrm{H}_{5}\right)$ ) and annual levels (high level $\left(\mathrm{H}_{\max }\right)$, low level $\left(\mathrm{H}_{\min }\right)$ ), were considered in particular. The lowest groundwater levels are $\mathrm{H}_{1}, \mathrm{H}_{5}$, which mostly coincide with the extreme level $\mathrm{H}_{\text {min }}$, and respectively, the highest groundwater levels are $\mathrm{H}_{3}$ or $\mathrm{H}_{\text {max }}$.

In Table 1 shows the coordinates (geographic latitude $\varphi^{\circ} \mathrm{N}$ and longitude $\lambda^{\circ} \mathrm{E}$ ) of the hydrogeological points, for which were conducted the following measurements of the groundwater levels are summarized as well as coordinates of the registered earthquakes, their energies (E) and energy classes $(\mathrm{K})$ and the Moon Phases $(\mathrm{NL}-$ the New Moon, PQ - the First Quarter of the Moon, PL - the Full-Moon, DQ - the Last Quarter of the Moon) observed at the fixation extremums and earthquakes.

While analyzing the Table 1, one may notice that the average value of the groundwater level equals 2.3-3.6 meters. The extreme levels, as a rule, were observed in the same months when the earthquake was registered. When the water levels are recorded before the earthquakes, the water rises closer to the surface in relation to the average value.

The authors may give the data under observation well No. 95p, as an ex ample, where the average level $\mathrm{H}_{\min }$ equals $3.94 \mathrm{~m}$, and the registered index that is fixed a day before the earthquake of 28.05.96 with the energy class $K=7.9$ amounts to $3.16 \mathrm{~m}$. This is closer to the surface by $0.78 \mathrm{~m}$ in comparison with the average value. It should be noted that in the Ivano-Frankivsk region, the abnormal quantity of the extreme precipitations was not observed in May of 1996. Such information may indicate the series of the Earth's break ups and rifts, along which the water rises before the earthquakes.

While analyzing the graphs of the extreme groundwater levels (Fig. 5), we can see that the minimum and maximum groundwater levels are in-phase during the second part of the New Moon Phase (NL), from the first to the third day within the First Quarter of the Moon Phase (PQ) and the 

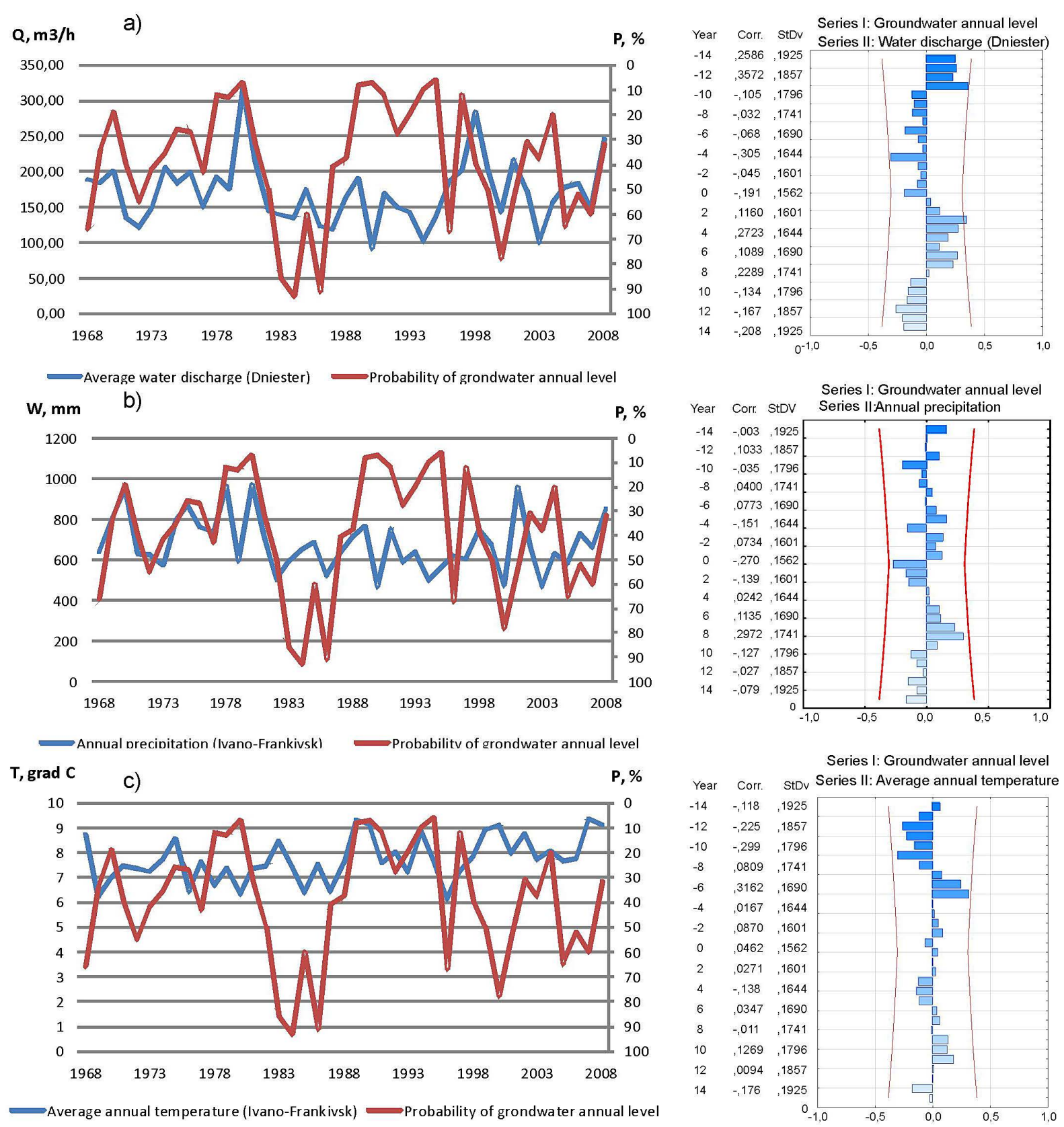

Figure 4. Estimation of interconnections peculiar to changing in groundwater levels and numerical characteristics of the regime creating factors applied for the monitoring stations in the Ivano-Frankivsk region: a) graphs and cross-correlation function for the groundwater level and surface water discharge; b) graphs and cross-correlation function for the groundwater level and annual amount of precipitation; c) graphs and cross-correlation function for the level of groundwater and average annual air temperature

Full Moon (PL) of the Moon cycle. The groundwater levels are in the antiphase during the second part of the Last Quarter Phase (DQ) during the twenty-fourth-twenty-sixth days as well as from the beginning of the New Moon Phase (NL) from the twenty-eighth to the thirties day.

As it seen from Table 2, the maximum groundwater levels are registered during the New Moon Phase (NL) ( 8 cases of 22 values were registered within the phase) and 2 days before the
First Quarter of the Moon Phase (PQ) (7 cases of 21 values registered within the phase), that constitutes $36 \%$ and $33 \%$, respectively.

There is a characteristic feature as to the registration of the minimum groundwater levels, which is conducted the next day of the phase. Such cases are registered during the New Moon (NL), the Last Quarter of the Moon Phase (DQ), the Full Moon (PL) (6-7 cases), which constitutes from $28 \%$ to $37 \%$ of the registered values within the phase. 
Table 1. Interconnection between the Moon Phases, earthquakes, and groundwater level

\begin{tabular}{|c|c|c|c|c|c|c|c|c|c|c|c|c|c|}
\hline \multicolumn{2}{|c|}{ Earthquaekes } & \multirow{2}{*}{$\begin{array}{l}\text { Date of } \\
\text { earthquake } \\
\text { registration }\end{array}$} & \multirow{2}{*}{$\mathrm{K}$} & \multirow{2}{*}{$\begin{array}{c}\mathrm{E} \times 10^{8} \\
\mathrm{~J}\end{array}$} & \multirow{2}{*}{$\begin{array}{c}\text { Well's } \\
\text { cadastral } \\
\text { number }\end{array}$} & \multirow{2}{*}{$\begin{array}{l}\varphi^{\circ} \mathrm{N} \\
\text { of well }\end{array}$} & \multirow{2}{*}{$\begin{array}{l}\lambda^{\circ} \mathrm{E} \\
\text { of well }\end{array}$} & \multirow{2}{*}{$\begin{array}{l}\text { Date of level } \\
\text { registration }\end{array}$} & \multirow{2}{*}{\multicolumn{2}{|c|}{$\begin{array}{l}\text { Day of the Lunar Cycle } \\
\text { and the Moon Phase }\end{array}$}} & \multirow{2}{*}{$\begin{array}{l}\text { Level of } \\
\text { ground- } \\
\text { water }(\mathrm{H}) \\
\end{array}$} & \multirow{2}{*}{$\begin{array}{c}\mathrm{H}_{\text {registere }} \\
\mathrm{m}\end{array}$} & \multirow{2}{*}{$\mathrm{H}_{\text {average }}, \mathrm{m}$} \\
\hline$\varphi^{\circ} \mathrm{N}$ & $\lambda^{\circ} \mathrm{E}$ & & & & & & & & & & & & \\
\hline 47.90 & 24.60 & 14.11 .74 & 9.5 & 31.60 & $113 p / e$ & 48.44 & 25.56 & 06.11 .74 & 23 & IDQ & $\mathrm{H}_{5}$ & 3.63 & 3.69 \\
\hline 47.97 & 24.51 & 14.11 .74 & 7.2 & 0.16 & $113 p / e$ & 48.44 & 25.56 & 06.11 .74 & 23 & IDQ & $\mathrm{H}_{5}$ & 3.63 & 3.69 \\
\hline 49.03 & 24.00 & 18.11 .74 & 7.6 & 0.40 & 113p/e & 48.44 & 25.56 & 06.11 .74 & 23 & IDQ & $\mathrm{H}_{5}$ & 3.63 & 3.69 \\
\hline 49.05 & 24.02 & 14.01 .76 & 11.0 & 1000.0 & $114 p$ & 48.44 & 25.57 & 03.01 .76 & 3 & $\mathrm{NL} / /$ & $\mathrm{H}_{1}$ & 2.98 & 3.16 \\
\hline 49.05 & 24.02 & 14.01 .76 & 11.0 & 1000.0 & 3 & 48.48 & 25.54 & 03.01 .76 & 3 & $\mathrm{NL} / /$ & $\mathrm{H}_{\text {min }}$ & 3.61 & 4.53 \\
\hline 49.05 & 24.02 & 14.01 .76 & 11.0 & 1000.0 & $95 p$ & 48.47 & 25.54 & 03.01 .76 & 3 & $\mathrm{NL} / /$ & $\mathrm{H}_{\text {min }}$ & 3.48 & 3.94 \\
\hline 47.83 & 24.75 & 11.06 .76 & 7.0 & 0.10 & $113 p / e$ & 48.44 & 25.56 & 06.06 .76 & 9 & $\mathrm{PQ} /$ & $\mathrm{H}_{\max }$ & 2.81 & 3.08 \\
\hline 47.83 & 24.75 & 11.06 .76 & 7.0 & 0.10 & $114 p$ & 48.44 & 25.57 & 06.06 .76 & 9 & $\mathrm{PQ} /$ & $\mathrm{H}_{\max }$ & 1.93 & 2.25 \\
\hline 47.83 & 24.75 & 11.06 .76 & 7.0 & 0.10 & $95 p$ & 48.47 & 25.54 & 06.06 .76 & 9 & $\mathrm{PQ} /$ & $\mathrm{H}_{\max }$ & 2.58 & 2.92 \\
\hline 48.95 & 24.07 & 31.10 .79 & 9.5 & 31.60 & $114 p$ & 48.44 & 25.57 & 30.10 .79 & 13 & $/ / \mathrm{PL}$ & $\mathrm{H}_{5}$ & 2.80 & 3.24 \\
\hline 48.05 & 25.00 & 13.07 .85 & 7.7 & 0.50 & $113 p / e$ & 48.44 & 25.56 & 27.07 .85 & 11 & & $\mathrm{H}_{\min }$ & 4.56 & 4.06 \\
\hline 48.05 & 25.00 & 13.07 .85 & 7.7 & 0.50 & $114 p$ & 48.44 & 25.57 & 06.07 .85 & 19 & & $\mathrm{H}_{\max }$ & 1.90 & 2.25 \\
\hline 47.70 & 24.50 & 28.08 .90 & 7.8 & 0.63 & $102 \mathrm{p} / \mathrm{e}$ & & & 27.08 .90 & 8 & IPQ & $\mathrm{H}_{5}$ & 1.80 & 2.02 \\
\hline 48.20 & 24.70 & 08.01 .93 & 7.6 & 0.40 & $102 \mathrm{p} / \mathrm{e}$ & & & 03.01 .93 & 11 & $\mathrm{PQ} / /$ & $\mathrm{H}_{\min }$ & 1.68 & 2.09 \\
\hline 48.80 & 24.29 & 16.08 .95 & 8.2 & 1.58 & $114 p$ & 48.44 & 25.57 & 09.08 .95 & 14 & /PL & $\mathrm{H}_{5}$ & 2.97 & 3.24 \\
\hline 48.69 & 24.40 & 28.05 .96 & 7.9 & 0.79 & $95 p$ & 48.47 & 25.54 & 27.05 .96 & 11 & $\mathrm{PQ} / /$ & $\mathrm{H}_{\min }$ & 3.16 & 3.94 \\
\hline
\end{tabular}

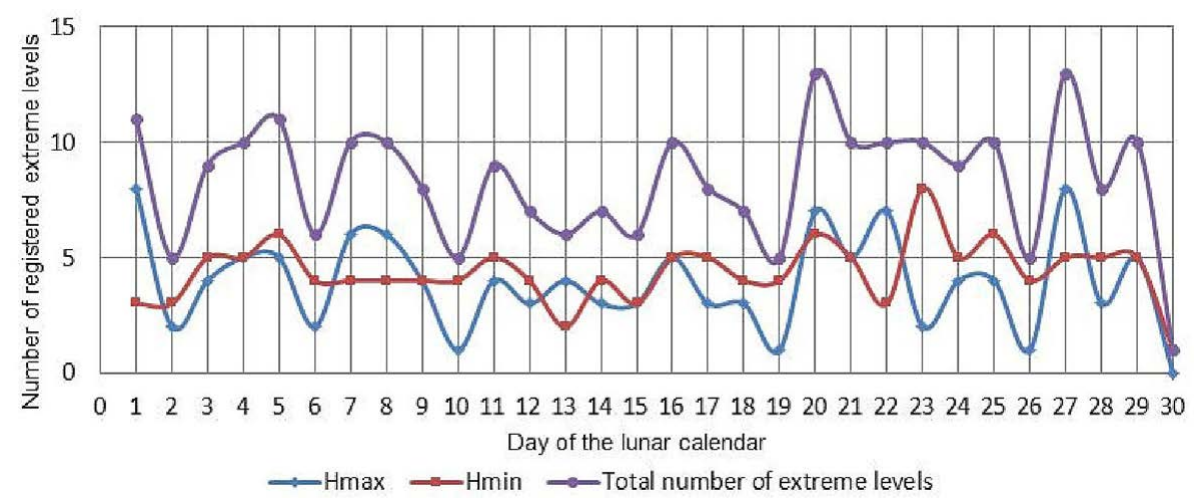

Figure 5. Dependency graph for a number of the registered extreme groundwater levels (by the lunar calendar

While considering the graphs of the extreme groundwater levels and number of the earthquakes both in the Ivano-Frankivsk region and in the adjacent territories with the energy class $\mathrm{K}>6$ (Fig. 6) for 1962-2003, we may notice an inverse relation. It is especially traced for maximum groundwater levels. The same trend is observed for the minimum groundwater levels from the first to third day of New Moon Phase (NL), during the First Quarter (PQ) and the full Moon (PL). However, since the second half of Full Moon Phase (PL) and during the Last Quarter Phase (DQ) we can notice a significant correlation between changing of minimum groundwater levels and registration of strong earthquakes with energy class $\mathrm{K}>6$ (correlation class from the fifteenth to thirties day of the Moon cycle equals 0.47 ).

We must also note the increase in seismic activity during the Full Moon Phase (PL), when it coincided with Perigee (the distance between the Moon and the Earth is the closest). Thus, eight cases of the registered earthquakes with energy class $K=7.1-9.1$ occurred during Perigee or within it $(\approx 2$ days $)$.

In the days of the New Moon Phase (NL) (from the first to seventh day) and the Full Moon (from the thirteenth to seventeenth day), we may observe the inverse relation, which is primarily agreed with Hmax, between the number of measurements of the extreme groundwater levels and number of the registered earthquakes. Only a graph of changing measurement of Hmin repeats the trend of the earthquake registration.

The maximum values peculiar to occurrence of the groundwater levels (Hmax) are most often registered during the First and the Last Moon Quarter (PQ and DQ). The coefficients of correlation equal 0.98 and 0.8 , respectively. It should 
Table 2. Interconnection between the Moon Phases, earthquakes, and groundwater levels

\begin{tabular}{|c|c|c|c|c|c|}
\hline \multirow{2}{*}{ The Moon Phase } & \multirow{2}{*}{$\begin{array}{l}\text { Day of the Lunar } \\
\text { Cycle }\end{array}$} & \multicolumn{3}{|c|}{ Number of registered extreme groundwater levels } & \multirow{2}{*}{$\begin{array}{c}\text { Number of } \\
\text { earthquakes with } K>6\end{array}$} \\
\hline & & $\mathrm{H}_{\max }$ & $\mathrm{H}_{\min }$ & Total number & \\
\hline$/ / \mathrm{NL}$ & 28,29 & 3 & 4 & 7 & 2 \\
\hline /NL & 29,30 & 5 & 5 & 10 & 1 \\
\hline $\mathrm{NL}$ & 1 & 8 & 2 & 10 & 5 \\
\hline $\mathrm{NL} /$ & 2 & 2 & 6 & 8 & 3 \\
\hline $\mathrm{NL} / /$ & 3 & 4 & 4 & 8 & 1 \\
\hline //PQ & 6,7 & 7 & 3 & 10 & 2 \\
\hline /PQ & 7,8 & 4 & 3 & 7 & 6 \\
\hline $\mathrm{PQ}$ & 9 & 2 & 3 & 5 & 3 \\
\hline $\mathrm{PQ} /$ & 8,9 & 5 & 4 & 9 & 1 \\
\hline $\mathrm{PQ} / /$ & 11,12 & 2 & 5 & 7 & 4 \\
\hline$/ / \mathrm{PL}$ & 13,14 & 4 & 1 & 5 & 5 \\
\hline /PL & $14,15,16$ & 4 & 5 & 9 & 2 \\
\hline $\mathrm{PL}$ & 15,16 & 4 & 3 & 7 & 6 \\
\hline PL/ & $16,17,18$ & 5 & 7 & 12 & 3 \\
\hline $\mathrm{PL} / /$ & 18,19 & 3 & 3 & 6 & 1 \\
\hline //DQ & 21,22 & 5 & 4 & 9 & 2 \\
\hline IDQ & 22,23 & 5 & 5 & 10 & 3 \\
\hline $\mathrm{DQ}$ & 23 & 2 & 5 & 7 & 3 \\
\hline $\mathrm{DQ} /$ & 23,25 & 2 & 6 & 8 & 3 \\
\hline $\mathrm{DQ} / /$ & 25,26 & 4 & 3 & 7 & 4 \\
\hline \multicolumn{2}{|c|}{$\begin{array}{c}\text { Total number of registered extreme } \\
\text { groundwater levels during the Moon Phases } \\
\text { / Total number }\end{array}$} & $80 / 118$ & $81 / 131$ & $161 / 249$ & $60 / 94$ \\
\hline
\end{tabular}

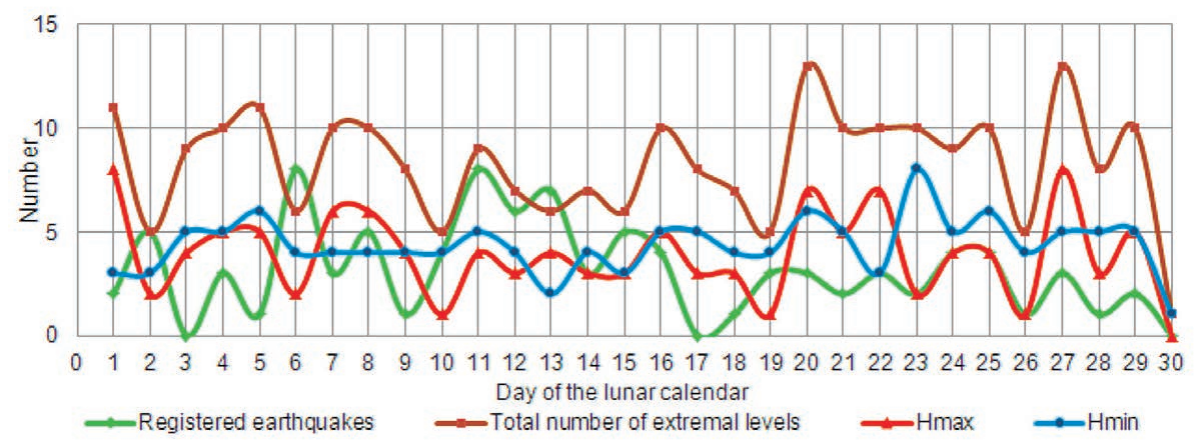

Figure 6. Graph of the earthquake numbers in the Ivano-Frankivsk region and the extreme groundwater levels (according to the lunar calendar)

be noted that 35 earthquakes were registered during PQ Phase; it constitutes $37 \%$ of the total number of the studied earthquakes. The minimal extreme values Hmin were also registered at that time and the coefficient of correlation is positive and equals 0.51 .

Thus, one may state that the tides occurring on the Earth during the Full Moon (PL) are one of the factors, which not only influence the changing in the occurrence of the groundwater levels but also cause the earthquakes (at that time 17 cases were registered, which equaled to $28 \%$ of the total number of earthquakes registered during the Moon Phases).
The registration of the extreme underground water levels Hmax and Hmin is in-phase in the days of the New Moon (NL), the coefficient of correlation equals 0.8-0.9. During the Full Moon (PL), the registration of Hmin decreases with the increasing of the earthquake number (the coefficient of correlation is negative $(-0.64)$. This shows a rise of the water level up to the surface. Such regularities may indicate an increase in probability of the earthquake arising in the days of the First Quarter (PQ), the Full Moon (PL), and the New Moon (NL) in seismic-active territories. 


\section{CONCLUSION}

It is necessary to review and expand the network of the observation wells as well as to provide the development and improvement of the automated database on the grounds of contemporary geo-informative technologies in order to ensure the functioning of the groundwater monitoring system. The geo-informative approach to decision of the hydrogeological monitoring tasks envisages the systematic use of geo-informative analysis for collection, process and storage of information. In addition, the approach aims at the creation of permanent hydrogeological models based on GIS and allows the efficient analysis of the spatially organized information obtained because of the regime observations. Moreover, the introduction of GIS-technologies permits to implement the basin principle for processing of the groundwater monitoring data while the single geodatabase within the groundwater monitoring system will allow the maximum preservation of the existing hydrogeological survey results, ensure the integration of heterogeneous data and their operational analysis. A complex analysis of the periodical observation data in the IvanoFrankivsk region, in particular, confirms the interconnections of the recording time of the seasonal and annual extremes peculiar to the groundwater levels with seismic activity and the lunar calendar. The results obtained may be used not only for clarification of the hydrogeological forecasts but also for the risk assessment of the earthquake arising in the adjacent territories.

\section{REFERENCES}

1. Adushkin V., Ryabova A., Spivak A. 2017. Effects of the moon-solar tide in the Earth crust and Earth atmosphere. Physics of the Earth, 4, 76-92.

2. Berezko O., Vasneva O. 2012. Groundwater monitoring in Belarus: implication and future prospects. Transboundary Aquifers in the Eastern Borders of the European Union, Springer Science+Business Media. Dordrecht, 115-120. DOI: 10.1007/978-94-007-3949-9_10.

3. Ben-JemaF.,MarinoM.A.,LoaicigaH.A.1994.Multivariate geostatistical design of groundwater monitoring networks. Journal of water resources planning and management-ASCE, 120, 505-522. DOI: 10.1061/(ASCE)0733-9496(1994)120:4(505).

4. Brovko A., Brovko G., Koshliakov O. 2015. Estimation of geosystem stability as a meth- odological approach for determination of the technogenic impact on groundwater (case study of quaternary aquifer on the territory of Rivne NPP). Visnyk of Taras Shevchenko National University of Kyiv: Geology, 69, 75-78. DOI: 10.17721/1728-2713.69.12.75-78.

5. Directive 2000/60/EC of the European Parliament and of the Council of 23 October 2000 establishing a framework for Community action in the field of water policy [official website]. http://eur-lex. europa.eu/resource.html?uri=cellar:5c835afb2 ec 64577 bdf 8756 d3d694eeb.0004.02/ DOC_1\&format=PDF [access: 29.01.2018].

6. Hudak P., Loaiciga H. 1992. A location modeling approach for groundwater monitoring network augmentation. Water Resources Research, 28, 643-649. DOI: 10.1029/91WR02851

7. Koshliakov O., Dyniak O., Koshliakova I. 2016. Hydrogeological and geoinformatical aspects of European standards implementation in Ukraine in the area of natural waters quality and water management. Proc. «Geoinformatics 2016» - XVth International Conference on Geoinformatics - Theoretical and Applied Aspects. http://www.earthdoc.org/publication/publication details/?publication $=84608$ [access: 18.02.2018]. DOI: $10.3997 / 2214-4609.201600507$.

8. Maréchal J.-C. et al. 2002. Establishment of earth tides effect on water level fluctuations in an unconfined hard rock aquifer using spectral analysis. Current Science, 83 (1), 101-104.

9. Pivovarova I. 2016. Optimization methods for hydroecological monitoring system. Journal of Ecological Engineering, 17(4), 30-34. DOI: 10.12911/22998993/64503.

10. Ruban S., Shinkarevsky M., Nikolishina A. 2005. Groundwater of Ukraine, Kyiv.

11. Shestopalov V. et al. 2010. Modern principles of hydrogeological zoning. Zbirnyk of scientific works of UkrSGEI, 3-4, 147 - 157.

12. Shestopalov V., Liuta N. 2016. State and ways of reforming the state groundwater monitoring system taking into account international experience and the requirements of the European Union Water Framework Directive. Mineral Resources of Ukraine, 2, 3-4.

13. Shtohryn L., Kasiyanchuk D. 2015. About the possible connection between periodicity of precipitation, activation of landslides and phases of the moon, Zbirnyk of scientific works of UkrSGEI, 4, 93-102.

14. Tymkiv M., Davybida L. 2016. Analysis of the state of hydrogeological monitoring network within the territory of Ukraine and the possibilities of its optimization on the basis of the geoinformation approach. Proc. International scientific and technical conference of young scientists «GeoTerrace-2016», 157-160. 